のであつて、從來は豊水期には出來得る限り 水力溌電により賄ひ、冬期渴水期に火力墢電的 より不足を補って来たのである。（第 6 圆參照）

終戰直前の空慜は主要火力發電所數ヶ所を大 破し、その復舊は一寸覺束ない狀態で、剩へ今 回の賠償により火力發䉓能力の約牛數が撤去さ れることとなるので今後は冬季渴水期に火力墢 電で不足電力を補充するだけの彈力性は殆ど期 待出來ない。闪上の樣な電力事情から見て電氣

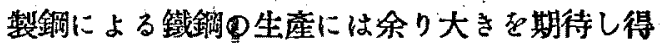
ないるのと考へられる。

3 其他の生産力式

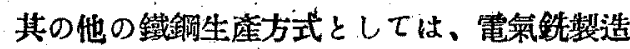
法、粗鎆及純鐵の製造法。直接電忽抵抗法、電

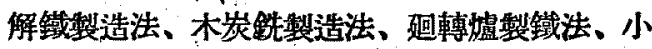
型熔鈸瓐製鐵法、海綿鐵製造法等があるが、何 れも電力、原料の純度、成品の不均質等の点か ら特别の條件に惠まれた特定の場所で小規模に 筫施する以外は殆んど企業的に經營不可能と看 へられる。

特柬の問題として、酸素添加笑風による製鐵

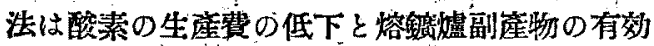

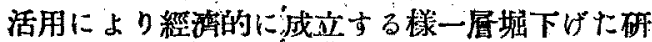
究が必要と考へられる。

\section{VIII 鐵鋼技術の向上方策}

今後の我が國鐵鋼界は、限ら礼た原料で優良 な製品支最も效果的に生詹しなげれぱならない のであうて、生産技衙の合理化等徹底的に遂行 しなけれでならな。

\section{1 製鐵原料の合理的活用方策}

\section{（1）鐵踱石の合理的使用方策}

從來使用の南方及中國の鐵銈石は大体に坽て 鐵分 $57 \%$ 以上であつたが、今日の國內鏣石は 鐵分が大体 47\% 以下である。鐵鍍石の品位の

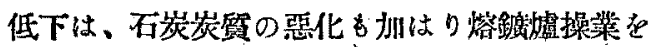
著しく不安定ならしもてるる、內地踱石は粉鉦

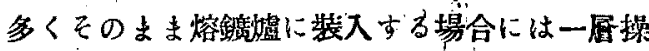

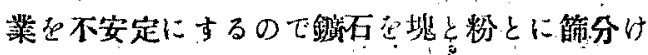

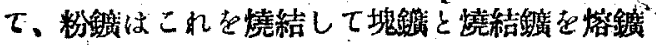

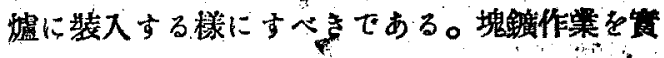
施すれば、出鐵量が20〜22\% 增加することる 明かにされたる。鐵鍍石使用の合理化は結論

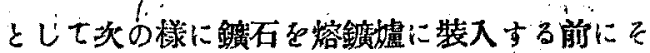
，の事前處理を充分筫施することである。

\section{a. 茭入原料の整備}

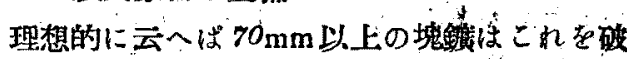
碎して70 mm以下とし、粉銹は箱分け憢結鎦

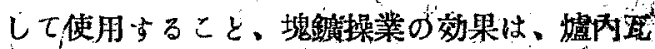
斯上界の均一化、透風矦力の但下、棚吊防止、 鏣石の還元性の均一化、等コークス比の低下、從

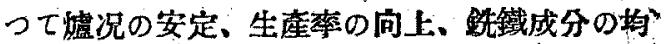

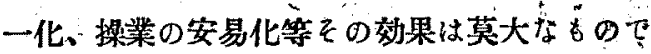
ある。

b. 原料の大さ别に上る高蠦操業

同一工場に 2 基以上の蕰憈がある場合は可及 的に原料サイズを佂别して操業し、同一嘘の使 用原料の大さを一定ならしめるといふしをす拷 へられる、をの原料の大さにより操策速度を拁 滅し、作業の標準化が可能となる。

c. 燒結鐿使用の强化

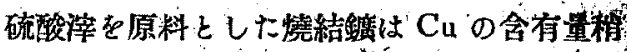

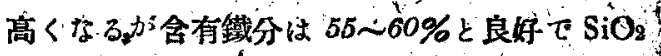

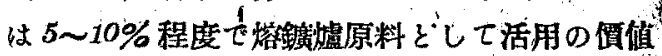

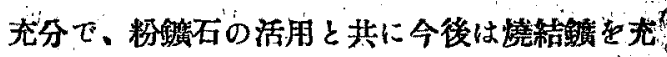
分活用すべきでる。

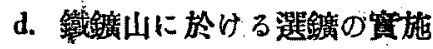

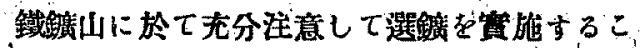
とが必要である。

（口）石炭の合理的使用方策

a. 原料炭の合理的使用

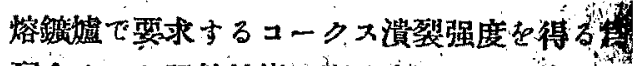
に配合す心゙き强粘結炭の配分率は、北松炭では 灰分方高い開係から 35〜40\%が適當て、華北 强粘結孷では可洗性す良好であるから任意の

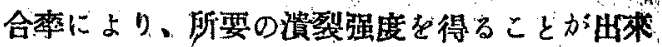
30

北海道炭等の弱粘結炭のみて溑裂强度の高い

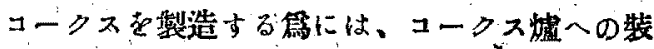

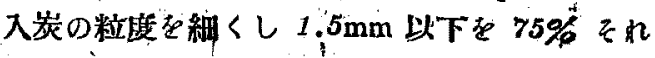


ising にンーライトの細粉を 15〜20\% 混合してュー

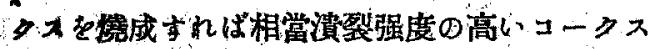
加得らんる、份一般に裝入㞸在微粉化すること によタンークスの强度は相澢に向上する。

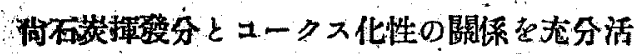
加して銘唡每の配合に注意すべきである。

b. 教生爈用炭の合理的使用

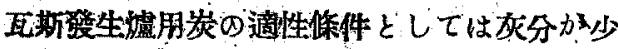

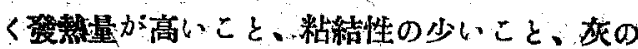

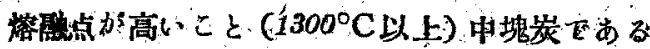

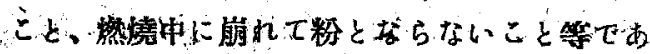

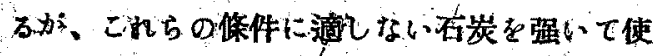

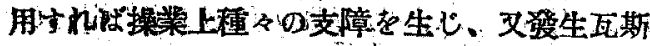
の成分に然て 决して滿足すべきのは得られ

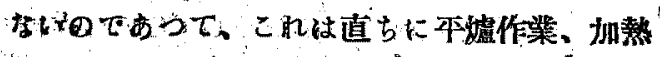

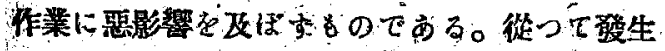

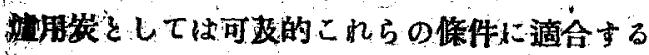

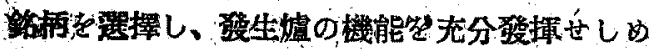
尖ければならな。

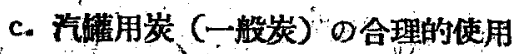

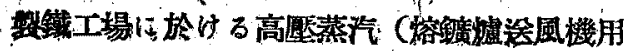

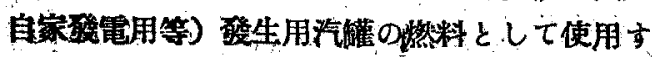

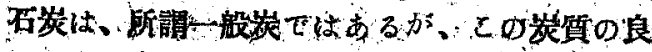

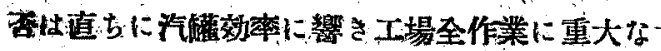

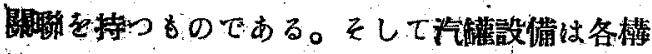

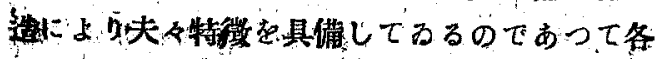

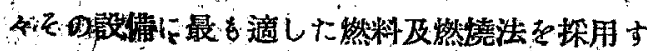
我市る。

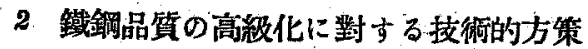

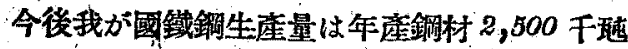
非制限されでるのであるから、この限られた

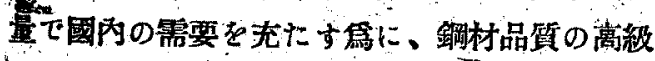
化老圆り、より少心鍓材て從前の目的起迲する 棒進まなければならない。

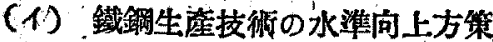

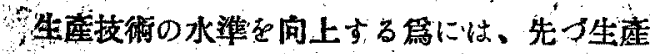

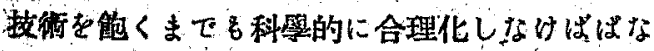

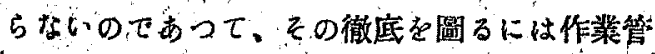

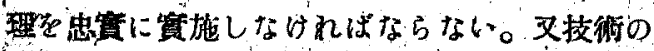

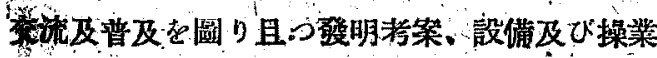

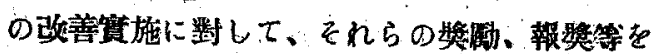

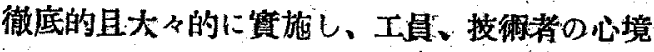
ほ常に躍野せしめなりればならない。

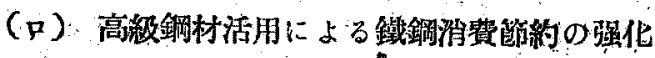
方策

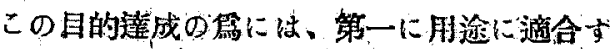

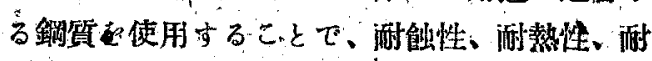
磨耗性、或は特殊の電雅的性筫力゙要求るれる場

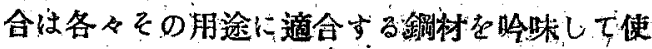

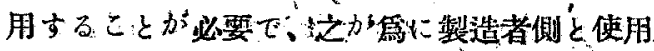

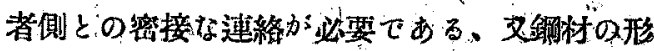
狀等を改善を要する点は速かに改善すべきたあ る、その外揢接技街の向上的圖り今後建筑物、 橋梁、船舶等に熔接を適用することにより錩材 の節約を圆る必要がある。何鍢籿に熱處理名施

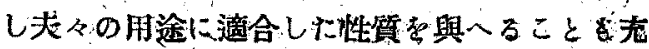

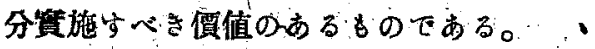

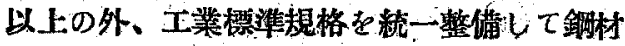
生產上及使用上にむ奇與せしめなければならな b.

\section{(N) 作業合理化の徽底}

住業の合理化に當つては、先つ作湈の機械化

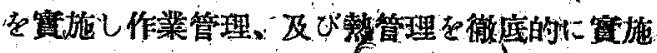

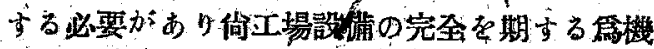

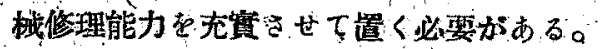

\section{X 鐵龬矼究機關の整備强化方策;}

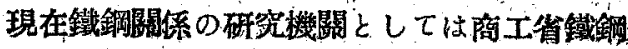

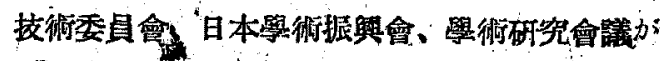

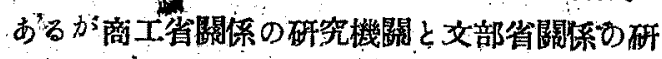
究機閵をのの結付きが充分でなく、その基礎學 的、學理的な研究の成果を工業化することが、 强力且適切に推進され葜い。この湶に研究の成

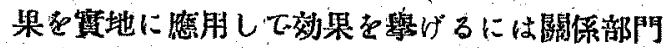

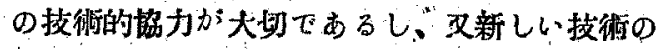

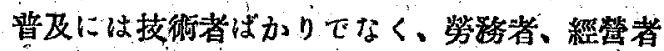

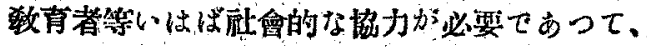
我が國の筫情ではこの問题を逶理する虎には學 會蛋强化して、これを利用するのが管賞と考へ られる。 


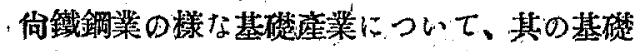

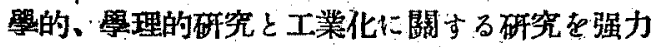

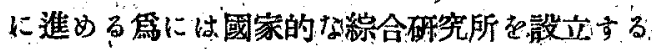
ことが何より有力な手段と考いられる、㤖研究

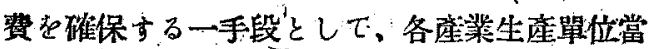

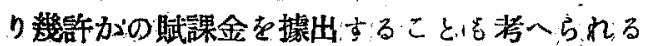
のだある。

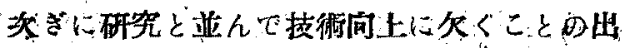

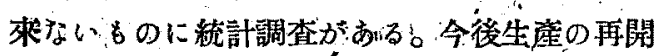

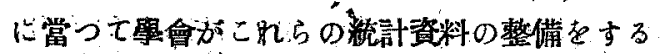
ささは極めて有意義のこ亡と考へられる。

\section{$X$ ，整鐵技術者票育の强化方策}

1.大藇專門學校に於ける教育課程の整備强化 今啳の教育のあり方として學生の偑性を伸長 する゙ことに重点を置かなければならい。從來

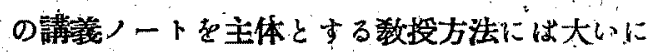

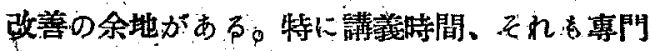

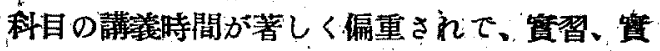
驗及づ工學一般に關する教育が制合に輕悓され てわる。

习大學專門學校に對する像算が形式にのみ捉 はれ、数十年来の額を踏警し、余りにも資弱で ある、昭和二十一年度の東京常國大學第一工拲

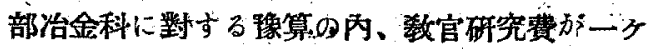
年一人虽僅加上教授 300 圆、助教授 120 圆、旅、

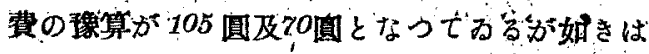
文化國蒙として全く批評の限りてない次第であ。 万。

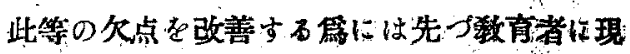
場の優秀な技術者相隹の待遇电以て招聘すべ

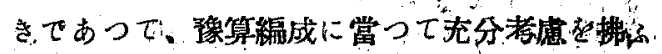
ベきである。同專任の教授吕全般的な講福を，

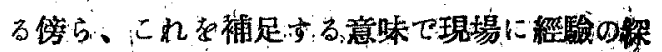

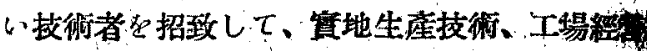

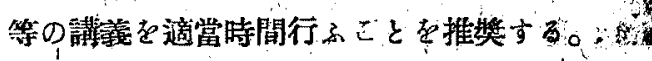

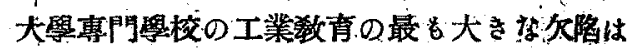

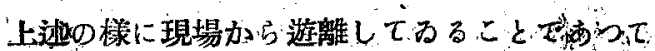

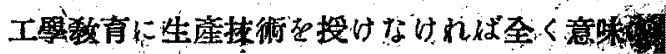

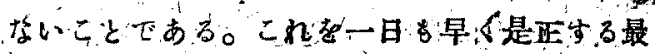

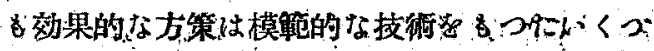

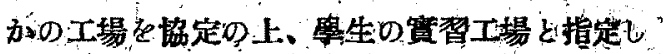

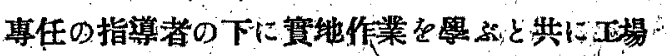

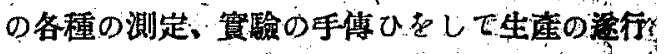
技街の向上に奇與するごとでる。

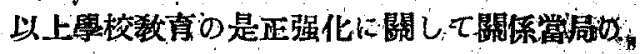

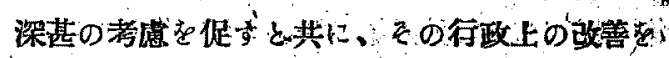
希望するす,のである。

2 ，現場技衡員の数育强化

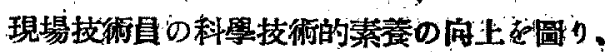

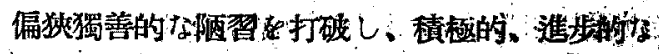

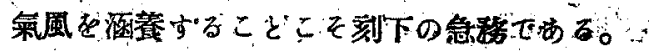

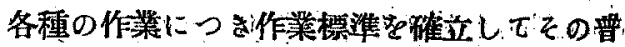

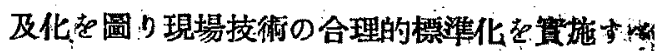

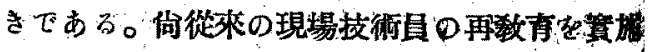

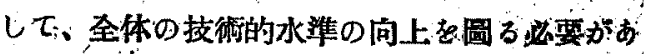
३o 